$11-2020$

\title{
Water diplomacy and shared resources along the United States- Mexico border
}

\author{
Maria Elena Giner \\ Gabriel Eckstein \\ Texas A\&M University School of Law, gabrieleckstein@law.tamu.edu
}

Follow this and additional works at: https://scholarship.law.tamu.edu/facscholar

Part of the Environmental Law Commons, International Law Commons, Natural Resources Law Commons, and the Water Law Commons

\section{Recommended Citation}

Maria E. Giner \& Gabriel Eckstein, Water diplomacy and shared resources along the United States-Mexico border, in River Basin Organizations in Water Diplomacy 72 (Anoulak Kittikhoun \& Susanne Schmeier eds., 2020).

Available at: https://scholarship.law.tamu.edu/facscholar/1510

This Book Section is brought to you for free and open access by Texas A\&M Law Scholarship. It has been accepted for inclusion in Faculty Scholarship by an authorized administrator of Texas A\&M Law Scholarship. For more information, please contact aretteen@law.tamu.edu. 


\section{River Basin Organizations in Water Diplomacy}

\section{Edited by \\ Anoulak Kittikhoun and Susanne Schmeier}


First published 2021

by Routledge

2 Park Square, Milton Park, Abingdon, Oxon OX14 4RN

and by Routledge

52 Vanderbilt Avenue, New York, NY 10017

Routledge is an imprint of the Taylor \& Francis Group, an informa business

(C) 2021 selection and editorial matter, Anoulak Kittikhoun and

Susanne Schmeier; individual chapters, the contributors

The right of Anoulak Kittikhoun and Susanne Schmeier to be identified as the authors of the editorial material, and of the authors for their individual chapters, has been asserted in accordance with sections 77 and 78 of the Copyright, Designs and Patents Act 1988.

All rights reserved. No part of this book may be reprinted or reproduced or utilised in any form or by any electronic, mechanical, or other means, now known or hereafter invented, including photocopying and recording, or in any information storage or retrieval system, without permission in writing from the publishers.

Trademark notice: Product or corporate names may be trademarks or registered trademarks, and are used only for identification and explanation without intent to infringe.

British Library Cataloguing-in-Publication Data A catalogue record for this book is available from the British Library

Library of Congress Cataloging-in-Publication Data

A catalog record has been requested for this book

ISBN: 978-0-367-21813-3 (hbk)

ISBN: 978-0-429-26627-0 (ebk)

Typeset in Times New Roman

by codeMantra 


\title{
3 Water diplomacy and shared resources along the United States-Mexico border
}

\author{
Maria Elena Giner and Gabriel E. Eckstein
}

The United States and Mexico are geographic neighbors with high economic asymmetry, but with intense shared history and deep social, cultural, economic, and security ties. Among these shared interests are 23 rivers and numerous aquifers along the 3,000 km border. ${ }^{1}$ Of these, two are the primary focus of the two governments, the Colorado and Rio Grande rivers. These scarce resources in the region, which ranges from semiarid in the west to arid in the center and humid in the east, require cooperation to manage and have been responsible for shaping much of the $170+$ year relationship.

In 2015, over 15.3 million people resided along the United StatesMexico border in ten states, which include 24 counties in the United States and 35 municipalities in Mexico. ${ }^{2}$ Ninety percent of the residents on the border live in 15 sister cities linked through trade, employment, culture, and education, among others (see Figure 3.1). ${ }^{3}$ Movement of goods and people across the border is part of everyday life in this region. For example, in 2016, over 180 million persons crossed into the United States from Mexico through the 55 ports of entry in personal vehicles or as pedestrians for purposes of tourism, shopping, or day trips. ${ }^{4}$ Also, the highest concentration of US manufacturing associated with foreign direct investment exists along the United States-Mexico border and is one of the most important sources of employment for this region. ${ }^{5}$ The population in the border region has grown at a faster pace than that of the general population in both the United States and Mexico. ${ }^{6}$ The accelerated growth along the border has aggravated the need for water and other basic infrastructure in a region where budgets allocated for such amenities are below required levels. As a result, human health and the environment in this region have been negatively impacted on both sides.

Common water supplies, including the border's two major rivers, the Colorado and Rio Grande (see Figure 3.2), and numerous 


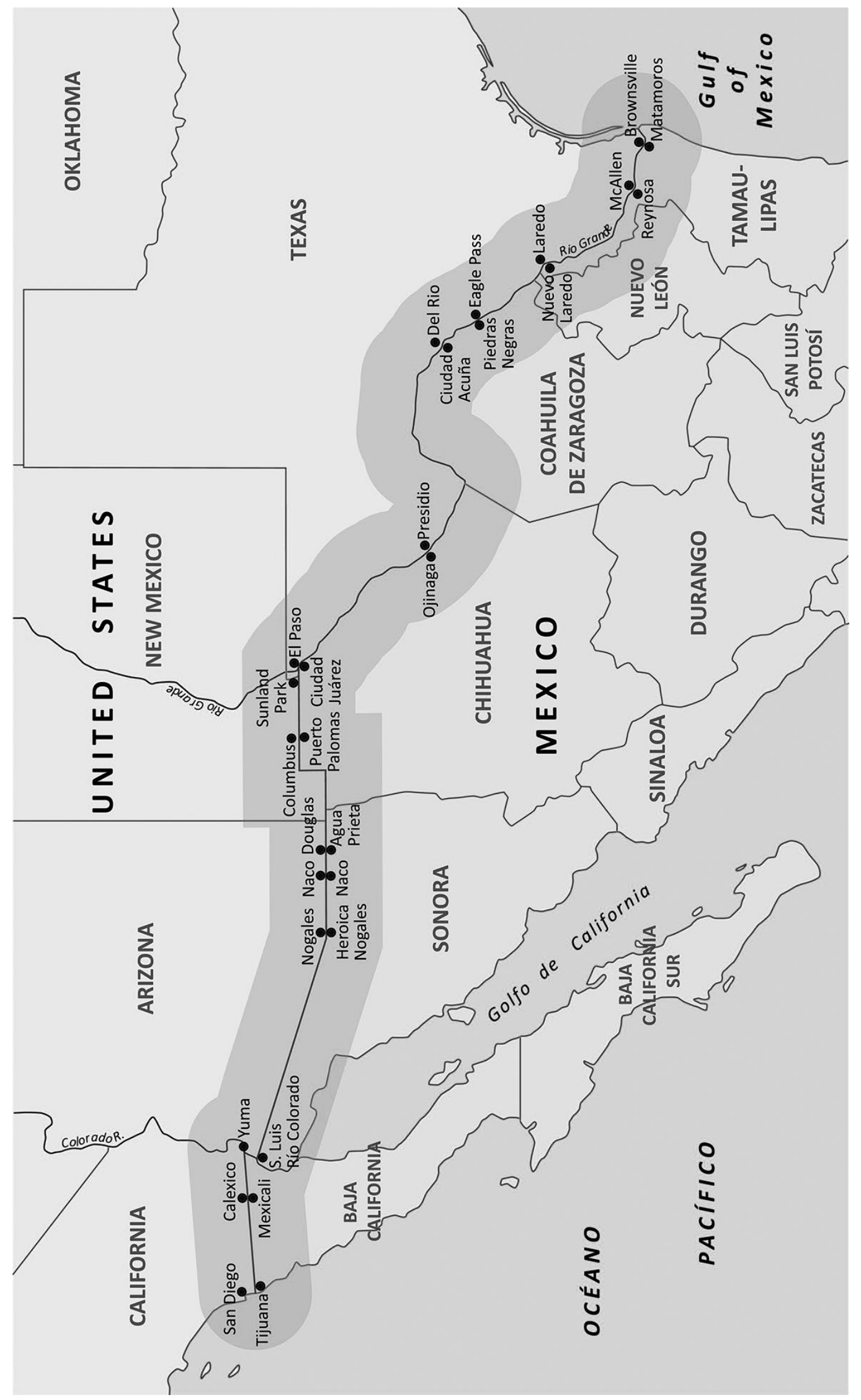

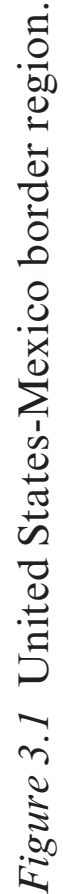




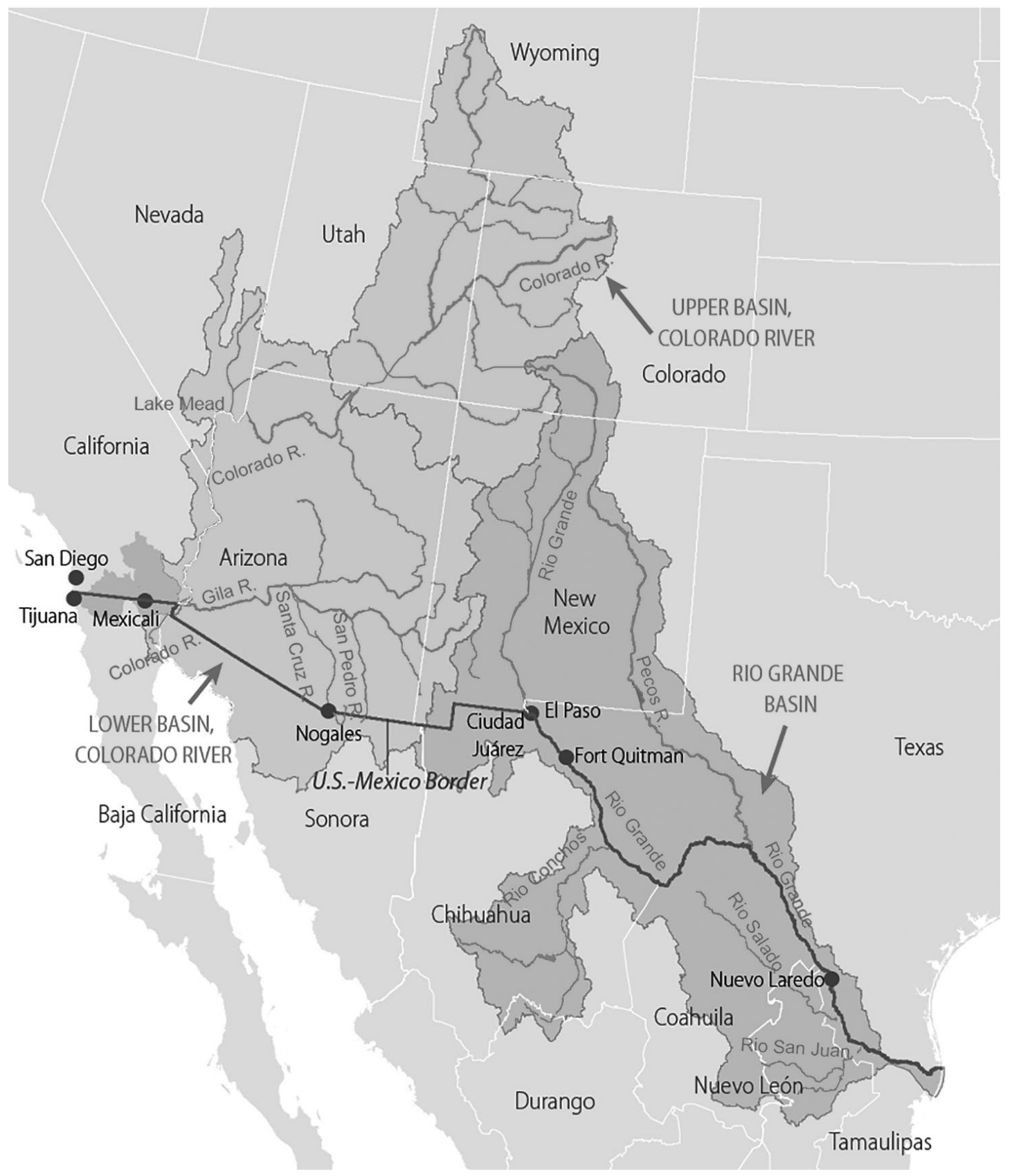

Figure 3.2 Colorado River and Rio Grande basins.

transboundary aquifers, have been negatively impacted by drought, overdraft, and pollution that have increased salinity levels and degraded water quality. About 97 percent of the basin of the Colorado River lies within the United States. Originating in the state of Colorado, the river's basin traverses Utah, Arizona, Nevada, and California before reaching Mexico. ${ }^{7}$ Approximately 40 million residents rely on Colorado and its tributaries for municipal use, of which 2 million are in Mexico. ${ }^{8}$ The Rio Grande River also originates in the state of 
Colorado and crosses New Mexico before forming the international boundary between Texas and Mexico. It is the fifth longest river in the United States and supplies water to more than six million residents in both countries. ${ }^{9}$ Since 1848, as populations and economic growth in the border region have continuously expanded, these two rivers have been the focus of cooperation between the United States and Mexico.

Today, the primary institutions involved in cooperation over water resources along the border include the International Boundary and Water Commission (IBWC) and the North American Development Bank (NADB). ${ }^{10}$ Scholarly literature consistently associates these two organizations with transboundary water issues and concurs on five basic premises: (1) much work has been accomplished along the border to address disputes and the discharge of wastewater into shared water bodies; (2) the North American Free Trade Agreement (NAFTA) injected much-needed attention on the need to address transboundary water pollution through wastewater infrastructure, as well as funding for such projects from the United States Environmental Protection Agency (EPA) and Mexico's National Water Commission (Conagua); (3) the IBWC and NADB are unique institutions with fairly robust systems for funding infrastructure and water governance respectively; (4) in the last 75 years, nearly every dispute related to transboundary water was resolved through cooperation; ${ }^{11}$ and (5) more work on transboundary water issues is needed related to supply, pollution, and usage, especially as it pertains to drought and climate change. ${ }^{12}$

Each organization has contributed to different elements of cooperation over shared water resources and pollution prevention in the border region. The IBWC has managed water allocation and water pollution, and the NADB has developed and financed infrastructure projects for local communities to address water pollution. Collectively, these activities have contributed to the prevention, mitigation, and resolution of water conflicts throughout the United States-Mexico border through cooperation ${ }^{13}$ and supported dispute prevention ahead of the need for resolution.

\section{Primary Mexico-United States treaties for transboundary waters}

A series of treaties between the United States and Mexico serve as the basis for cooperation over shared water resources in the border region. See Figure 3.3 for a timeline of these agreements.

The earliest treaty was signed shortly after the Mexican-American War: the 1848 Treaty of Peace, Friendship, Limits, and Settlements 


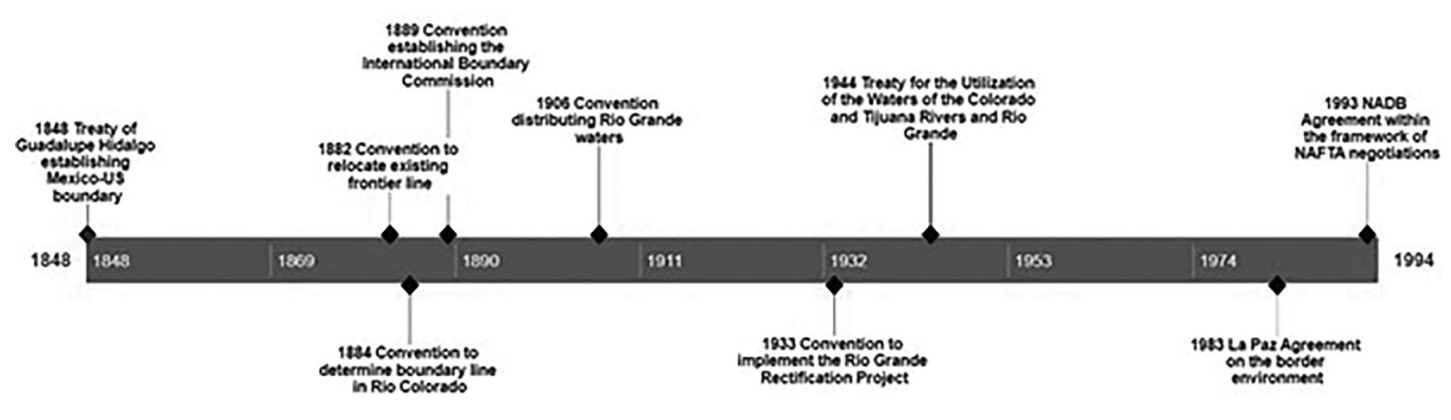

Figure 3.3 Timeline of relevant treaties identified by the authors.

between the US and Mexico. ${ }^{14}$ This agreement established the physical boundaries between the two countries and designates the Colorado and Rio Grande rivers to become international basins. The agreement was followed by five lesser, but still significant conventions, through which the two countries cooperated on a range of issues: placement of boundary monuments; boundary disputes related to meandering rivers; establishment of the International Boundary Commission (IBC); allocation of water in a segment of the Rio Grande; and construction of the commission's first joint infrastructure project, the Rio Grande Rectification Project.

In 1944, the two countries entered a new treaty that continues to guide and influence water management and allocation decisions in the border region today. The Treaty for the Utilization of Waters of the Colorado and Tijuana Rivers and of the Rio Grande (1944 Water Treaty) authorized the joint construction and operation of two dams along the lower basin of the Rio Grande, expansion of the IBC's jurisdiction to include water and, thereby, creation of the IBWC, and distribution of the waters of the major cross border watersheds: the Colorado River, Tijuana River, and Rio Grande. ${ }^{15}$ It also tasked the IBWC by addressing border sanitation issues with a transboundary impact.

In the Colorado River, under Article 10 of the 1944 Water Treaty, the United States is required to ensure Mexico receives 1,850,234,000 cubic meters of water annually. In the Rio Grande, the treaty recognizes the bifurcation of the river as two separate basins and allocates only the waters of the lower basin amongst the two countries in specific terms. Under Article 1 of the 1906 Convention between the United States and Mexico "Equitable Distribution of the Waters of the Rio Grande," the United States is required to deliver 74,008,800 cubic meters annually of water to Mexico from the upper basin. Article 4 of the 1944 Water Treaty allocates to Mexico two-thirds and to the United States one-third of the waters of six Mexican tributaries (Conchos, 
San Diego, San Rodrigo, Escondido, and Salado rivers, and the Las Vacas Arroyo), which collectively must amount to at least 431,721,000 cubic meters per year averaged over a five-year cycle. ${ }^{16}$ The 1944 Water Treaty also apportions to Mexico the entire flow of two Mexican tributaries, the San Juan and Alamo rivers, while the United States is allotted the entire flow of seven US tributaries: the Pecos and Devil's rivers, the Alamito, Terlingua, San Felipe, and Pinto creeks, and Goodenough Spring. The remaining waters in the lower Rio Grande basin are shared equally under the treaty. ${ }^{17}$

A distinctive element of the 1944 Water Treaty is the linkage embedded into the agreement that includes the distribution of waters from two rivers in two geographically different regions along the border serving different basins. Itay Fischhendler et.al. argue that this arrangement has constrained the ability of the two nations to adapt management regimes in response to the unique environmental stresses of each river. ${ }^{18}$ Yet, Minutes 318, 319, and 323-which responded to reduced flows in the Colorado and environmental degradation in the Colorado delta, and created a mechanism for Mexico to store its water allocations within the US - suggest such concerns can be addressed through the IBWC's unique minute system for interpreting and implementing the 1944 Water Treaty. Fischhendler et.al. also highlight that while Mexico receives water from, but does not contribute to, the Colorado River's volume, the United States receives more water from the entire Rio Grande than it contributes to that river. ${ }^{19}$ To some extent, it appears that in developing the 1944 Water Treaty, the parties traded water from one watershed in exchange for water from another, an option that would not have been readily available had they negotiated separate agreements for each river.

While, on balance, this arrangement may appear fair to some and unfair to others, it was the product of more than 20 years of negotiations involving issues beyond the mere allocation of water, including population pressures, sanitation, droughts and floods, economic development, and border security. ${ }^{20}$ Such pressures may have contributed to the two nations expanding the scope of the treaty to the three rivers in order to have more options for negotiating their respective priorities. Moreover, there may be an advantage to having only one institution with responsibility for all three rivers as the delivery and use of water across borders often involves multiple diverse stakeholders with broadly different interests. If ever the treaty was opened for renegotiations, the consolidated approach could allow the two nations to fully consider all the diverse interests and priorities, as well as the implications for all of the encompassed river basins. ${ }^{21}$ 
More recently, the United States and Mexico entered into two additional agreements that expanded their transboundary interests beyond water, but have proven to be critically important for water management because of the actors brought into the conversation. On 14 August 1983, the United States and Mexico signed the Agreement on Cooperation for the Protection and Improvement of the Environment in the Border Area (La Paz Agreement), which serves as the basis for bilateral cooperation on environmental protection in the border zone, defined as $100 \mathrm{~km}$ north and south of the international line. ${ }^{22}$ The agreement stipulates obligations related to consultation, information sharing, review of environmental concerns, annual meetings, and formal reporting. ${ }^{23}$ It also designates the respective federal environmental agencies as the coordinators, thereby tasking the EPA and Mexico's Secretariat of Environment and Natural Resources (SEMARNAT) with protecting human health and the environment and obligating them to monitor and measure pollution levels related to water and air. Moreover, it obligates them to consult with state and municipal governments, nongovernmental organizations, and others on cooperative measures. ${ }^{24}$

Initially, the La Paz Agreement was used as a diplomatic instrument between the two governments through its respective environmental agencies to establish goals and objectives primarily related to water, air, and land issues. More recently, it has become a mechanism to provide joint funding. Binational initiatives include the Integrated Border Environmental Plan (1992-1994), Border XXI (1995-2000), Border 2012 (2001-2012), and Border 2020 (2013-2020). ${ }^{25}$ The latter's goal of access to clean and safe water includes objectives on increasing household water and sewer connections for the communities along the border, assisting utilities to build capacity, watershed protection through reduction of surface water contaminants, and sharing of water quality data for transboundary watersheds by both federal governments. ${ }^{26}$ It also calls for additional investment in water resource management. Under the auspices of the La Paz Agreement, these programs serve as an institutional framework for cooperation between the two governments, raise awareness of environmental issues along the border, and provide a certain level of legitimacy that further strengthens engagement among the various government agencies, most notably the IBWC, which has authority over transboundary water issues. ${ }^{27}$

Development of the goals and objectives of the La Paz Agreement is based on stakeholder engagement and a system of five taskforces geographically distributed along the border. ${ }^{28}$ Taskforce members include representatives from state and local governments, tribal groups, 
academia, and nongovernmental organizations. This grassroots approach, managed binationally by EPA and SEMARNAT, follows a process of engagement through conferences with experts on water, air, and land issues, a yearly national conference, and various public comment opportunities. To some extent, this participatory approach has provided legitimacy to the goals and objectives set under the framework of the La Paz Agreement with each successive program building on the previous one.

During the early 1990s when NAFTA was being negotiated, environmentalists expressed their growing dissatisfaction with the results of the La Paz Agreement. ${ }^{29}$ They had expected more attention and resources from the two federal governments and highlighted worsening environmental conditions in the border region where some of the poorest communities were located. During this time, many communities along the border did not have wastewater treatment, and pollution of transboundary rivers was an issue. Broadening support for NAFTA presented an opportunity to raise awareness of these conditions on the coattails of that agreement's authorization process, and to link the border's environmental health to trade.

As a result, the two countries were pressed by environmental stakeholder groups to sign an agreement within the framework of the negotiations of NAFTA, known formally as the Agreement between the Government of the United States of America and the Government of the United Mexican States Concerning the Establishment of a Border Environment Cooperation Commission and a North American Development Bank (NADB Agreement). ${ }^{30}$ It created the NADB, which diverged in structure and process from the IBWC and included water pollution, wastewater treatment, and other priorities within its mandate. Moreover, the NADB is truly a binational institution equally funded by both governments. Over the past 170 years, the implementation and evolution of these agreements along the United States-Mexico border have created a unique governance structure for cooperation.

\section{The organizations}

The IBWC, initially called the International Boundary Commission when it was created in 1889 , changed to the current name under the 1944 Water Treaty in recognition of its expanded jurisdiction, which now included the waters traversing the border. This broader authority authorized the IBWC to engage in binational solutions for issues that arose during the application of United States-Mexico treaties regarding water-related boundary demarcation and rights to transboundary 
waters, as well as issues related to sanitation, water quality, and flood control in the frontier. The US Section has its principal offices in El Paso, Texas, while the Mexican Section operates across the border in Ciudad Juarez, Chihuahua. Both sections also have seven field offices spread out along the border. Each section receives funding and policy guidance from its respective diplomacy agency, the US Department of State and Mexico's Foreign Ministry.

All staff of the IBWC are federal employees of their respective country. The leadership team in each country includes a commissioner, who must be an engineer and is appointed directly by the president of the respective country, two principal engineers, a legal advisor, and a foreign affairs secretary. ${ }^{31}$ The management staff is composed primarily of technically oriented professionals and is proud of its reputation as an engineering agency that gives policy guidance based on science. This unique element of management is the basis of the IBWC's legitimacy, which has been called engineering diplomacy. ${ }^{32}$ While its original priority focused on maintaining the international boundary, its authority has now grown to include water quantity and quality management, border sanitation, and emergency water supplies. Stephen Mumme suggests that

most important, the Commission has evolved as both a diplomatic and technical agency, with primary responsibilities for enforcing and interpreting the provisions of the international treaties with which it is entrusted, and anticipating and designing solutions to new problems within its jurisdiction. ${ }^{33}$

The IBWC collectively owns and operates major infrastructure including flood control levees and five diversion dams, as well as two major reservoirs with power plant facilities located on the Rio Grande: Amistad and Falcon dams. ${ }^{34}$ This infrastructure is used to manage water delivery for both countries from the Rio Grande and Colorado River and is needed to address portions of the mandate associated with water quality monitoring, transboundary water deliveries, and flood control. As part of its sanitation mandate, the IBWC also owns and operates three international wastewater treatment plants. These facilities were built to address untreated wastewater flows primarily originating from Mexico and flowing into the United States. However, the Nogales facility also treats wastewater from both Nogales, Arizona and Nogales, Sonora. Funding for the construction, operation, and maintenance of these facilities is provided by both countries. Over the last 30 years, no significant infrastructure facilities have been built 
in the border region, although the IBWC has rehabilitated a number of existing facilities.

The 1944 Water Treaty also allows the IBWC to document decisions involving the application of its mandate through minutes, binding instruments between the two governments. ${ }^{35}$ These are agreements covering a range of cross-border issues that mostly address demarcation, operation, and maintenance of its infrastructure, water delivery related to drought and eco-systems, construction or rehabilitation of dams and other facilities, water quality issues such as salinity in water delivery, and water pollution and sanitation issues that cross the international boundary, such as stormwater and untreated wastewater. Minutes are developed between the two IBWC sections and validated by the respective foreign affairs units. ${ }^{36}$ Once a minute is approved by both countries through the IBWC and confirmed by the two governments within a 30-day review period, minutes are considered part of the treaty. As of July 2019, 324 minutes have been issued by the IBWC. $^{37}$

The IBWC focuses its efforts on engineering activities and solutions that may be proactive or reactive. Its actions are mostly technical, with limited stakeholder involvement and within the limits of its authority under the 1944 Water Treaty. Despite its long-standing operations, its location on the border and away from the capitals of the respective countries, some scholars have suggested that the IBWC is outmoded and needs to innovate, be less insular, and expand its public engagement efforts. ${ }^{38}$ One has called the IBWC "a social artifact, imperfect at best, and captive to the vicissitudes of time." 39 Stakeholders have also expressed disappointment with the progress made on environmental issues. Some have claimed that the IBWC's narrow focus on water resources in the border region has led to the neglect of other critical concerns, including air quality and land conservation. While it may have been logical to expand its mandate, they believe that the IBWC's lack of agility to respond to emerging issues, its heavy focus on engineered solutions, and poor stakeholder engagement have not favored this path. As a result, some have argued that the La Paz Agreement, which created the NADB, was adopted because of the IBWC's deficiencies. ${ }^{40}$

The NADB itself was created in 1993 with a strict mandate related to the development and implementation of environmental infrastructure. It works in coordination with state and federal agencies by assisting local communities to improve environmental conditions and advance the well-being of residents in both nations. Although the organization does not own any infrastructure, its programs provide technical assistance, grants, loans, and capacity building to utilities, municipalities, 
academia, and the private sector for infrastructure development and implementation. The NADB's leadership team consists of a chief executive officer and chief operating officer of opposite nationalities, appointed by each government and confirmed by its Board of Directors (BOD). Unlike the IBWC, the NADB is an international organization with two contributing countries - the United States and Mexico. Its BOD consists of ten members, five from each country. Four are members of the public at large and six come from federal agencies. Its employees are of both Mexican and US nationalities, co-located at its offices in San Antonio and Ciudad Juarez, and benefit from certain diplomatic immunities.

The NADB is capitalized in equal parts by the US Treasury and Mexico's Ministry of Finance. Its operations and programs are funded by the interest earned on its capital and funds from the US State Department and SEMARNAT. It also receives program funds from the EPA, to disburse as grants to local communities along the border, under the auspices of the Border 2012 and Border 2020 programs and the Border Infrastructure Fund (BIF). This has considerably improved water quality by eliminating the discharge of untreated sewage.

The NADB has been called the most consequential of the NAFTAgenerated institutions because of its significant impact on the border environment since its creation, especially as its actions relate to transboundary water pollution. ${ }^{41}$ This was possible precisely because the NADB was provided with important government backing from multiple federal agencies. Since 1993, funding provided to the NADB from the EPA, the US Treasury, Us State Department, and Mexico's Finance and Environment ministries has exceeded $\$ 1$ billion. ${ }^{42}$ The NADB has earned significant legitimacy with stakeholders in border states and cities, as well as within academia. It also has implemented successful projects in just about every major community along the border. As of August 2017, its accomplishments included the funding of 147 water and wastewater projects for various utilities, benefitting almost 13 million residents. The improvements in wastewater alone have a capacity to eliminate 462 million gallons per day of untreated or inadequately treated sewage. ${ }^{43}$

Prior to the NADB's efforts, only 21 percent of Mexican residents along the border with the United States were connected to wastewater treatment facilities and typically discharged untreated sewage into shared waterbodies on the frontier. Today, nearly 90 percent of that population is connected to wastewater management facilities, significantly reducing an important source of pollution. ${ }^{44}$ Similarly, on the US side, prior to 1993 , there were over 400,000 residents in 
unincorporated communities known as colonias in Texas and New Mexico that did not have wastewater treatment services and that discharged their sewage into shared surface or groundwater bodies. ${ }^{45}$

Yet despite its successes in implementing infrastructure projects, the NADB also has its challenges. It implements individual projects in response to requests submitted by municipalities. ${ }^{46}$ As a result, broader watershed issues are not addressed comprehensively and are simply cobbled together through individual local efforts. Currently, there is no strategy in place at the NADB to address water management holistically, include groundwater, or consider issues related to drought or climate change.

\section{Future challenges along the border}

As is typical of most watersheds, especially those in arid climates, water is not always accessible in the quantity, quality, or location where it is needed. Over-allocation of available water resources, prolonged droughts, and pollution are common challenges. In the United States-Mexico border region, such challenges have sparked various disputes, most notably pertaining to three primary issues: delivery of water at specified times and volumes, water quality deficiencies mostly related to salinity and pollution, and conservation for the protection of the environment. To date, many of these disputes have been managed under the 1944 Water Treaty by the IBWC through the minute process, and for water pollution through the NADB funding programs. Two important conflicts have been resolved through IBWC cooperation: Mexico's water debt to the United States in the Rio Grande for the accounting cycle of 1997-2002; and pulse flow water deliveries in the lower portion of the Colorado River to begin restoration of the river's delta ecosystem in Mexico, which has been designated as a United Nations Biosphere Reserve. ${ }^{47}$ Other more recent conflicts that have not been fully resolved include the lining of the All-American Canal in Arizona, which lowered groundwater levels across the border in Mexicali, and stormwater pollution flows from Tijuana, Baja California into San Diego, California during precipitation events.

However, as droughts and climate change continue to impact the availability of water resources, and growing communities continue to affect water quality, the challenges facing the border region will need ongoing attention. In addition, the region faces new concerns related to untreated wastewater from collapsing sewer lines in cities adjacent to the international boundary, inadequately operated wastewater treatment plants, and contaminated stormwater from growing 
cities that primarily flow from Mexico into the United States. Unfortunately, neither country has given sufficient attention to the environmental impacts that these pollution concerns have had on estuaries, fisheries, and recreational areas.

The La Paz Agreement and NAFTA through the NADB Agreement have brought much attention to water issues along the border at the highest levels of government. Key agencies such as the EPA and SEMARNAT have also entered the water diplomacy arena previously dominated by the IBWC. This has introduced a different approach to decision-making and water-related project development given the EPA's public transparency and regular engagement process, which is in sharp contrast to the IBWC's insular history reinforced by the 1944 Water Treaty's omission of any required procedures for public participation or review of operations. ${ }^{48}$ In addition, the public process associated with the La Paz Agreement and NADB Agreement has empowered local communities, states, nongovernmental organizations, and academia to demand more from the IBWC. This unwanted attention from the public has further strengthened the negative perception of an IBWC that is slow to respond to challenges and criticism, interprets its scope very narrowly, and heavily focuses its efforts on engineered solutions. ${ }^{49}$

Although the NADB has also received the same pressures related to public engagement, unlike the IBWC it has specific requirements for engaging the public. These requirements were likely implemented because the organization was conceived as part of an environmental agenda and the EPA was directly involved in their creation. Furthermore, the EPA has provided the NADB with supplemental funds in the form of grants to address water and sanitation issues, which furthered the latter's achievements. Those funds were managed by the NADB and were used to leverage matching funds from Conagua and other state programs. These relationships and programs developed a diverse skill set within the NADB related to projects that include engineering, finance, and environmental awareness, as well as public engagement.

The IBWC and NADB have two areas in which their activities overlap. The first relates to water pollution where both organizations worked on the issues. However, while the IBWC has not constructed any major infrastructure in at least 30 years, the NADB regularly continues to conduct ribbon-cutting ceremonies for newly funded infrastructure. Not surprisingly, these efforts have given the NADB a role in water diplomacy as well. The second area of overlap is the limited geographical region in which both organizations work, which 
has facilitated a more localized approach. As compared to other federal or development agencies, whose locations are in Washington, DC and Mexico City, the IBWC and NADB's leadership and staff live in or near border communities and are exposed to the region's daily challenges. This provides local communities with quick, direct, and low-cost access to the institutions, and sensitizes staff to local needs.

Nonetheless, the differences between the IBWC and NADB are important. The IBWC functions as two separate but integrated federal agencies with independent sections representing their respective governments. As an institution, the IBWC has had a long history of activity, an established process of operations, a heavy engineering focus, no funding for community infrastructure, and a reputation for being isolated and limited in the interpretation of its own authority. The established purpose, process, and rules that created the agency have remained relatively consistent over its 130 years, and its mandate has been interpreted rather narrowly. As a result, the IBWC could find it difficult to adjust its operations in response to new challenges. Nevertheless, the organization has a strong and stable foundation grounded in long-standing treaties, full federal backing, and assets that it owns and operates.

In contrast, the NADB is an international organization with much less federal oversight, a shorter history, established public engagement processes, multi-skilled binational staff, and available funding for infrastructure. However, its limited mandate and project-specific focus constrains its ability to create policy level and holistic solutions related to water supply and quality.

Despite the IBWC's stability and NADB's flexibility, neither provides an ideal model of operation. For example, it is unclear whether either entity has the mandate to address the more than 30 aquifers that traverse the border. With the exception of pumping restrictions on the Yuma Aquifer under Minute 242, none of the aquifers have any management, allocation, or conservation mechanisms. Ironically, groundwater is a major regional concern because subsurface depletion can affect surface flows in adjacent rivers, pollution can negatively impact groundwater quality, and drought can affect both rivers and groundwater. In a similar vein, neither the IBWC nor NADB have the capacity to develop the scientific analyses needed to ascertain how the border region will be affected by climate change. In general, cooperation remains unsystematic and ad hoc and lacks a broader vision for the management of the shared water resources between the two nations. ${ }^{50}$ 


\section{Conclusion}

This chapter has shown that the existing river basin organization (RBO) framework is insufficient to address challenges in the basins and has overlaps and important gaps. Cooperation has been achieved through the minute process of the IBWC but has been limited to the narrow scope of the Colorado, Rio Grande, and Tijuana rivers. Other mechanisms used to address border water issues include various binational federal efforts, such as the La Paz Agreement and NADB Agreement. Both instruments have been used to remedy the gaps unaddressed by the IBWC, most importantly providing a mechanism for public engagement on water management issues at the state and local levels. However, their success has been limited to the extent that they have only created a patchwork of local project agreements rather than a comprehensive mechanism.

To add to this patchwork, a binational groundwater assessment program was initiated as a basis for information exchange through the US Geological Survey and Conagua. ${ }^{51}$ While coordinating with the IBWC, it is not clear if any single institution will serve as an RBO. The institutional requirements and legal regimes in each country are quite distinct and would require multi-level and multi-jurisdiction agreements to create such an RBO.

Natural resources are limited, and freshwater is diminishing in availability and quality along the United States-Mexico border. The vitality of communities along the border depends on these rivers and groundwater resources. Although the two countries have experienced challenges and disputes since their creation, over the past 170 years a treaty-based institutional framework for surface water has provided the governance mechanisms needed to promote cooperation over conflict. ${ }^{52}$ Both the NADB and IBWC have been successful in applying their respective mandates because they were institutionally located along the border, their leadership was required to be technocrats rather than bureaucrats or diplomats, and they were structured to facilitate trust between the two countries. The IBWC has also been successful because of its singular structure as a binational federal agency with two sections, each responding to and advocating for its respective country. Moreover, each section was given authority to enter into agreements through the very unique minute system by which the agreements are crafted on the border and then sent to the respective capitals for approval/rejection. In addition, the structure of the NADB as a single international organization with both Mexican and American nationals co-located and governed by a binational board 
has engendered trust from states and local communities as a neutral party. Combined with its history of achievement and management of significant funds, the NADB has gained considerable recognition and respect among the border states and local communities in a relatively short time.

Yet, more needs to be done for both surface and subsurface water resources, and the challenges that they face from drought and climate change. In particular, the lack of meaningful cooperation over the region's shared aquifers with a clear authority eventually could become a source of dispute between the two countries. In addition, currently there is no strategy in place to address water management holistically or to consider issues related to drought or climate change.

At the moment, there seems to be little appetite to expand the purview of the IBWC or NADB and put one of these in charge of a strategy for comprehensive water management, much less with the authority to manage all water resources on the border. While expanding the IBWC's authority may seem like the most obvious solution, the NADB's efforts in recent years have diverted attention and considerable funding away from the IBWC. As a result, gaps in management and cooperation are likely to continue in the border region and for its residents, especially as water becomes scarcer and demand continues to grow.

\section{Notes}

1 Linda Fernandez, "Transboundary Water Management along the U.S. Mexico Border," in Frontiers in Water Resource Economics, ed. Goetz Renan-Ulrich and Berga Dolors (New York: Springer, 2006), 154.

2 EPA and SEMARNAT, "State of the Border Region Indicators Interim Report 2016," Border 2020: US-Mexico Environmental Program, 2016, 5, https://www.epa.gov/sites/production/files/2017-01/documents/state_of_ the_border_region_2016_122216.pdf.

3 EPA and SEMARNAT, "State of the Border Region Indicators Report 2010," Border 2012: U.S-Mexico Environmental Program, 2012, 7, https:// www.epa.gov/sites/production/files/documents/border-2012_indicatorrpt_eng.pdf.

4 United States Department of Transportation Bureau of Transportation Statistics, "Border Crossing/Entry Data," https://www.bts.gov/content/ border-crossingentry-data.

5 Angeles Villarreal, "U.S.-Mexico Economic Relations: Trends, Issues, and Implications," Congressional Research Service, 2012, 6-7, 9, https:// apps.dtic.mil/dtic/tr/fulltext/u2/a584258.pdf.

6 Dennis Soden, "At the Cross Roads: US/Mexico Border Counties in Transition," IPED Technical Report, Institute for Policy and Economic Development, University of Texas, El Paso, Paper 27, 2006, 2-1, https:// digitalcommons.utep.edu/iped_techrep/27/. 
7 Nicole Carter, Stephen Mulligan, and Clare Ribando Seelke, "U.S.Mexican Water Sharing: Background and Recent Developments" Congressional Research Service, 2017, 9, https://crsreports.congress.gov/product/ $\mathrm{pdf} / \mathrm{R} / \mathrm{R} 43312 / 8$.

8 US Department of Interior Bureau of Reclamation, "Reclamation: Managing Water in the West_Colorado River Basin Water Supply and Demand Study," Executive Summary, 2012, 3, https://www.usbr.gov/water smart/bsp/docs/finalreport/ColoradoRiver/CRBS_Executive_Summary_ FINAL.pdf.

9 US Section of the IBWC, "About the Rio Grande," https://www.ibwc.gov/ CRP/riogrande.htm.

10 In December 2017, the NADB merged with its sister agency the Border Environment Cooperation Commission (BECC) in order to eliminate overlap, streamline operations, and improve impacts on the residents of the United States-Mexico border. Before the merger, both organizations worked in tandem to assist communities in developing and implementing environmental infrastructure along the frontier. Although there is substantial literature on the BECC, its functions are now executed by the NADB. Therefore, any reference in this paper to BECC will be incorporated as the NADB.

11 Fernandez, "Transboundary Water Management along the U.S. Mexico Border," 161-166; Robert C. Bonner and Andres Rozental, "Managing the United States-Mexico Border: Cooperative Solutions to Common Challenges," Full Report of the Binational Task Force on the United States-Mexico Border, 2009, 11, https://www.wilsoncenter.org/sites/default/ files/PCIP\%20Comexi \%20Full\%20Report-\%20english\%20version.pdf.

12 Jorge Alejandro Silva-Rodríguez de San Miguel, "Water Management on the Mexico-US Border: A Review of the Literature," Management of Environmental Quality: An International Journal 29, no. 2 (2018): 289-304.

13 Ibid.

14 US Section of the IBWC, "Treaties between the U.S. and Mexico," https:// www.ibwc.gov/Treaties_Minutes/treaties.html.

15 Ibid.

16 Carter, Mulligan, and Ribando Seelke, "U.S.-Mexican Water Sharing."

17 Utilization of Waters of the Colorado and Tijuana Rivers and of the Rio Grande (Treaty between the United States of America and the Mexico), 1944, 9-10.

18 Itay Fischhendler, Eran Feitelson, and David Eaton, "The Short-Term and Long-Term Ramifications of Linkages Involving Natural Resources: The US-Mexico Transboundary Water Case," Environment and Planning C: Government and Policy 22, no. 5 (2004): 633-634.

19 Ibid., 642-644.

20 See generally Kirsten Anderson, "A History and Interpretation of the Water Treaty of 1944," Natural Resources Journal 2, no. 4 (1972): 600-614.

21 Fischhendler, Feitelson, and Eaton, "The Short-Term and Long-Term Ramifications of Linkages": 647.

22 EPA and SEMARNAT, "State of the Border Region Indicators Interim Report 2016," 4.

23 Stephen Mumme and Kimberley Collins, "The La Paz Agreement 30 Years On," Journal of Environment and Development 23, no. 3 (2014): 304. 
24 Ibid., 305.

25 Ibid., 308.

26 EPA, "U.S.-Mexico Border 2020 Program," https://www.epa.gov/border2020.

27 Mumme and Collins, "The La Paz Agreement 30 Years On," 311.

28 EPA, "Border 2020 Organizational Structure," https://www.epa.gov/border 2020/organization.

29 Mumme and Collins, "The La Paz Agreement 30 Years On,” 316.

30 The agreement was amended twice for the purpose of increasing the efficiency and effectiveness of the BECC and NADB. The first was in 2002 where the Boards of Directors were merged into one, and the area of jurisdiction increased in Mexico from 100 to $300 \mathrm{~km}$. The second was in 2015 when the BECC and NADB merged into one institution.

31 Carter, Mulligan, and Ribando Seelke, "U.S.-Mexican Water Sharing," 5-6.

32 Stephen Mumme, "Engineering Diplomacy: The Evolving Role of the International Boundary and Water Commission in U.S.-Mexico Water Management," Journal of Borderlands Studies 1, no. 1 (1986): 73-108.

33 Ibid., 74.

34 US Section of the IBWC, "Diversion Dams and Related Structures," https://www.ibwc.gov/Mission_Operations/Diversion_Dams.html.

35 Carter, Mulligan, and Ribando Seelke, "U.S.-Mexican Water Sharing," $5-6$.

36 Ibid.

37 US Section of the IBWC, "Minutes between the United States and Mexican Sections of the IBWC," https://www.ibwc.gov/Treaties_Minutes/ Minutes.html.

38 Mumme and Collins, "The La Paz Agreement 30 Years On," 306, 323-324.

39 Stephen Mumme, "Innovation and Reform in Transboundary Resource Management: A Critical Look at the International Boundary and Water Commission," Natural Resources Journal 33, no. 1 (1993): 94.

40 Mumme and Collins, "The La Paz Agreement 30 Years On," 311-312.

41 Ibid., 312.

42 North American Development Bank, "North American Development Bank 2016 Annual Report,” 2017, 15, 23, https://www.nadb.org/uploads/ files/annual_report_fy_2016_english.pdf.

43 The Border Environment Cooperation Commission, "BECC-NADB Environmental Infrastructure Projects for the Border Region Sustainability," 2017, 2.

44 North American Development Bank and Border Environment Cooperation Commission, "20 Years 1994-2014: A Celebration of Progress," 2014, 105, https://www.heinkedesign.com/flipbooks_view/NADBHISTORY/ HistoryBook.html.

45 Soden, "At the Cross Roads," 8-14. Also see Texas Office of the Secretary of State, "Tracking the Progress of State Funded Projects that Benefit Colonias," 84th Texas Legislature Regular Session, 2014, 14, 27, https://www. sos.state.tx.us/border/forms/2014-progress-legislative-report.pdf.

46 Silva-Rodríguez de San Miguel, "Water Management on the Mexico-US Border," 294.

47 Carter, Mulligan, and Ribando Seelke, "U.S.-Mexican Water Sharing," 12-14, 21-24. 
48 Mumme, "Innovation and Reform in Transboundary Resource Management," 94, 118-119.

49 Ibid. 94; Nicole Carter \& Leonard Ortolano, "Working Toward Sustainable Water and Wastewater Infrastructure in the US-Mexico Border Region: A Perspective on BECC and NADBank," International Journal of Water Resources Development 16, no. 4 (2000): 692; and Silva-Rodríguez de San Miguel, "Water Management on the Mexico-US Border," 292.

50 Bonner and Rozental, "Managing the United States-Mexico Border."

51 Carter, Mulligan, and Ribando Seelke, "U.S.-Mexican Water Sharing," $12-14,21-24$.

52 Polioptro Martinez-Austria, Luis Derbez, and Maria Elena Giner, "The US-Mexico Institutional Arrangement for Transboundary Water Governance," in Free Flow: Reaching Water Security through Cooperation, United Nations Education, Scientific and Cultural Organization (UNESCO) (Paris: UNESCO, 2013), 182-185. 